\title{
PERAN PEMUDA SEBAGAI PENERUS TRADISI SAMBATAN DALAM RANGKA PEMBENTUKAN KARAKTER GOTONG ROYONG
}

\author{
Pramudyasari Nur Bintari, Cecep Darmawan \\ Departemen Pendidikan Kewaganegaraan, SPs, UPI, email: sarisubayani@yahoo.com
}

\begin{abstract}
Currently youth behavior that is inconsistent with the character of the nation and the declining youth awareness of the splice. This study aims to obtain a picture of the implementation of mutual cooperation, shape, splice conservation efforts, associated with the formation of the youth character and know the community efforts to increase the appreciation of youth. The study used a qualitative approach, descriptive methods. Subjects were young, village, and community leaders. Data collection technique used observation, interview, and documentation study. Data were analyzed using data reduction, and conclusion. Results of the research is the role of youth as the next generation of tradition, study and understand the traditions, accompany the next generation in the process of understanding, implementation, and evaluation. The role of youth in the splice should be improved as a form of community service. Splice form is "sinoman", "ngecor", recitals, help-aids at the funeral home, and community service. Splice as a medium that can build youth paradigm of mutual cooperation. Community efforts to increase the appreciation of youth by creating a modern activity, understand youth with psychological condition, and creating entrepreneurship training.
\end{abstract}

Keywords: youth, splice tradition, mutual cooperation, character.

\section{PENDAHULUAN}

Pemuda merupakan pewaris generasi yang seharusnya memiliki nilai-nilai luhur, bertingkah laku baik, berjiwa membangun, cinta tanah air, memiliki visi dan tujuan positif. Pemuda harus bisa mempertahankan tradisi dan kearifan lokal sebagai identitas bangsa. Pendidikan formal yang dilakukan juga harus menjadi bekal untuk bergaul dalam masyarakat. Wahab dan Sapriya (2011, hlm. 311) mengidentifikasikan bahwa warga negara yang baik yaitu: Warga negara yang memahami dan mampu melaksanakan dengan baik hak dan kewajibannya sebagai individu, peka dan memiliki tanggung jawab sosial, mampu memecahkan masalahnya sendiri dan masalah kemasyarakatan sesuai fungsi dan perannya (socially sensitive, socially responsible, dan socially intelligence), agar dicapai kualitas pribadi dan perilaku warga masyarakat yang baik (socio civic behavior dan desirable personal qualities).

Pemuda menjadi perhatian dari berbagai kalangan di segala bidang. Peran pemuda dalam masyarakat sebagai apresiasi pembelajaran di sekolah bahwa pendidikan kewarganegaraan merupakan salah satu upaya dalam proses pembentukan warga negara yang baik. Sebagaimana dikemukakan oleh Cogan dan Derricott (Sapriya 2011, hlm. 33), citizenship lebih mengarah pada karakteristik warga negara karena menyangkut berbagai dimensi pendidikan, politik, sosial budaya, dan ekonomi. Peran pemuda yang disebutkan dalam UndangUndang Negara Republik Indonesia Nomor 40 tahun 2009 tentang Kepemudaan pasal 16 tentang peran pemuda yaitu: "Pemuda berperan aktif sebagai kekuatan moral, kontrol sosial, dan agen perubahan dalam segala aspek pembangunan nasional." Dalam masyarakat sangat diperlukan peran pemuda sebagai penerus nilai-nilai luhur budaya bangsa, sebagai pondasi dan kekuatan moral, agen perubahan ke arah yang lebih baik.

Permasalahan generasi muda yang dikemukakan oleh Suryadi (2014, hlm. 45) yaitu menurunnya jiwa idealisme, patriotisme, dan nasionalisme serta kekurangpastian generasi 
muda tentang masa depan, belum seimbangnya jumlah generasi muda dengan fasilitas pendidikan yang tersedia, kurangnya kesempatan dan lapangan kerja, masalah gizi rendah menjadi hambatan bagi perkembangan kecerdasan dan pertumbuhan badan, banyaknya perkawinan dibawah umur, generasi muda yang menderita tuna fisik, mental dan sosial, dan pergaulan termasuk penyalahgunaan narkotika dan obatobatan terlarang. Selanjutnya, penulis melihat dari berbagai media televisi, bahwa yang terjadi di masyarakat adalah: Dalam bidang ekonomi khawatir dengan masalah lapangan pekerjaan dan masa depannya, dalam bidang sosial, pemuda saling bersaing untuk mendapat pengakuan orang lain, dalam bidang agama, tentunya sangat sedikit pemuda yang serius dan konsisten untuk berada di jalur yang benar sesuai tuntunan agama, dalam bidang budaya bisa dihitung berapa jumlah pemuda yang mau belajar tentang kebudayaan untuk melestarikannya. Adanya pernyataan yang mengatakan bahwa kebudayaan atau hasil karya jaman dulu itu kuno, sehingga masuklah budaya-budaya baru dari luar negeri yang dianggap modern.

Kaitannya dengan Pendidikan Kewarganegaraan, bahwa visi PKn ialah terwujudnya suatu mata pelajaran yang berfungsi sebagai sarana pembinaan watak bangsa (national and character building) dan pemberdayaan warga negara. Pemuda menjadi aktor penting dalam memantapkan watak dan karakter Pancasila. Terlebih perannya di masyarakat sebagai implementasi dari pembelajaran di sekolah. Pemuda harus paham tentang hak dan kewajibannya sebagai pelopor dan pemberi contoh kepada masyarakat lainnya dan menjalankan tanggung jawabnya sebagai anggota masyarakat. Ditambahkan oleh (Somantri dalam Wahab dan Sapriya, 2011, hlm. 311) melukiskan warga negara yang baik adalah warga negara yang patriotik, toleran, setia terhadap bangsa dan negara, beragama, demokratis, dan Pancasila sejati.
Hal tersebut sesuai dengan pernyataan Linton (dalam Koentjaraningrat, 1990, hlm. 53) yang menyatakan bahwa "Ciri-ciri watak yang sama pada sebagian besar warga dewasa dalam masyarakat itulah yang merupakan kepribadian umum masyarakat dan kebudayaan yang bersangkutan. Bentuk kerjasama yang nyata dilakukan dalam masyarakat ialah gotong royong. Sebagaimana Rasulullah SAW juga sangat menganjurkan umatnya untuk saling tolong menolong dalam kehidupan. Sesuai perintah Allah SWT dalam (QS. Al-Maidah: 2) "Saling tolong menolonglah kalian dalam kebaikan dan ketakwaan dan janganlah kalian saling tolong menolong dalam perbuatan dosa dan permusuhan".

Sejarah tolong menolong di Indonesia sangat akrab disebut gotong royong, sebagaimana Kaelan (2013, hlm. 59) bahwa: "Semangat gotong royong mengungkapkan cita-cita kerakyatan, kebersamaan dan solidaritas sosial. Berdasarkan semangat gotong royong dan asas kekeluargaan, negara mempersatukan diri dengan seluruh lapisan masyarakat." Hal tersebut diperkuat dengan sejarah yang mengatakan bahwa, penyederhanaan Pancasila yang pada intinya adalah gotong royong, Kaelan (2013, hlm. 25) bahwa ada lima prinsip sebagai dasar negara kemudian oleh Soekarno diperas menjadi Trisila yang meliputi; Sosionasionalisme, sosiodemokrasi dan ketuhanan. Kemudian beliau juga mengusulkan bahwa Trisila dapat diperas menjadi Ekasila yang intinya adalah gotong royong.

Korelasi gotong-royong sebagai nilai budaya, Bintarto (1980, hlm. 24) mengemukakan, Nilai itu dalam sistem budaya orang Indonesia mengandung empat konsep; manusia itu tidak sendiri di dunia ini tetapi dilingkungi oleh masyarakatnya, manusia tergantung dalam segala aspek kehidupan kepada sesamanya, harus selalu berusaha memelihara hubungan baik dengan sesamanya, dan selalu berusaha untuk berbuat adil dengan sesamanya. 
Memudarnya nilai gotong royong terjadi apabila rasa kebersamaan mulai menurun dan setiap pekerjaan tidak lagi bersifat sukarela, bahkan hanya dinilai dengan materi atau uang. Sehingga jasa selalu diperhitungkan dalam bentuk keuntungan materi, akibatnya rasa kebersamaan makin lama akan semakin menipis dan penghargaan hanya dapat dinilai bagi mereka yang memiliki dan membayar dengan uang. Kondisi yang serba materi seperti saat ini telah menjadikan nilai-nilai kebersamaan yang luhur semakin luntur dan tidak lagi bernilai.

Modernisasi telah mempengaruhi kegiatan kerja sama sambatan, dulu masyarakat saling membantu karena mereka saling peduli dan dalam kegiatan sambatan tidak menuntut untuk mempunyai keahlian tertentu yang terpenting adalah kebersamaan dan solidaritas pada masyarakat. Akan tetapi adanya modernisasi telah merubah perilaku masyarakat, adanya tenaga ahli dan adanya sistem pengupahan menjadi kebiasaan untuk diterapkan dalam masyarakat, tidak terkecuali pada kegiatan sambatan. Seiring berkembangnya zaman, tenaga ahli semakin beragam dapat ditemukan, hal tersebut semakin lama dikhawatirkan akan mempengaruhi kegiatan dalam bentuk kerja sama seperti kegiatan sambatan. Tidak menutup kemungkinan tenaga ahli juga dapat ditemukan dengan mudah di daerah pedesaan. Sebab itu, dikhawatirkan kegiatan sambatan mulai ditinggalkan masyarakat dan mempengaruhi solidaritas masyarakat desa yang pada umumnya solid.

Di dalam masyarakat, pemuda merupakan penerus cita-cita perjuangan bangsa dan sumber bagi pembangunan bangsa karena pemuda sebagai harapan bangsa dapat diartikan bahwa siapa yang menguasai pemuda akan menguasai masa depan. Seperti yang diungkapkan oleh Mangunhardjana (1986, hlm. 17) bahwa: Kaum muda yang ada dalam proses pertumbuhan dan perkembangan serta dalam situasi yang berbeda yang tidak selalu mudah, merupakan bagian dari keseluruhan bangsa. Oleh karena itu mereka tidak dapat dipisahkan dari masalah-masalah yang dihadapi oleh bangsa.

Proses sosialisasi pemuda dapat membantu individu melalui belajar dan penyesuaian diri. Proses sosialisasi berawal dari dalam keluarga. Melalui proses sosialisasi, pola pikir pemuda akan berwarna dan beragam, pemuda menjadi tahu bagaimana ia bertingkah laku di tengah-tengah masyarakat dan lingkungan budayanya. Berkaitan dengan hal tersebut, Mangunhardjana (1989, hlm. 14) menyatakan bahwa : Perkembangan sosial kaum muda menyangkut perluasan jalinan hubungan dengan orang lain. Dengan lewatnya umur kanak-kanak dan berkat pertumbuhan fisik mereka, pergaulan kaum muda tidak terbatas lagi dengan orang-orang dalam lingkungan keluarga, tetapi meluas ke teman-teman sebaya, orang-orang di lingkungan tempat tinggal dan masyarakat luas.

Perubahan dan kondisi masyarakat sebagai penentu peranan pemuda yang ditentukan oleh kemampuannya dalam mengatasi permasalahan-permasalahan yang ada pada setiap jamannya, sehingga tidak ketinggalan informasi yang pada akhirnya bisa mengatasi dan mempersiapkan solusi yang tepat. Manusia pada dasarnya selalu hidup di dalam suatu lingkungan yang serba berpranata. Artinya segala tindak tanduk atau perilaku manusia senantiasa diatur menurut cara-cara tertentu yang telah disepakati bersama. Menurut Koentjaraningrat (1990, hlm. 164) pranata adalah: "Suatu sistem norma khusus yang menata suatu rangkaian tindakan guna memenuhi suatu keperluan khusus dari manusia dalam kehidupan bermasyarakat."

Dalam ilmu antropologi terdapat pranata sosial atau institusi sosial yang mengakomodir kepentingan manusia agar dapat memenuhi kebutuhan dalam hidup di tengah-tengah masyarakat. Selain memenuhi kebutuhan yang diperlukan oleh masyarakat, pranata sosial dapat pula menjadi sarana untuk pembangunan 
karakter bangsa, karena dalam pranata sosial tersebut terkandung nilai-nilai diantaranya gotong royong, tanggung jawab, ketaatan terhadap ajaran agama, serta persatuan dan kesatuan bangsa.

Pengertian pranata sosial adalah sistem norma yang bertujuan untuk mengatur tindakan maupun kegiatan masyarakat. Dengan kata lain, pranata sosial adalah sistem hubungan sosial yang terorganisir dan mengejewantahkan nilainilai serta prosedur umum yang mengatur dan memenuhi kegiatan pokok dalam masyarakat. Kaitan antara pemuda dengan budaya adalah bahwa budaya dalam arti luas dianggap sebagai pengetahuan dan nilai-nilai yang diturunkan dari generasi ke generasi dalam sebuah kelompok sosial. Pemahaman nilai-nilai sebagai unsur dan hakikat kebudayaan sangat penting dalam mempelajari antropologi budaya. Nilai-nilai budaya adalah jiwa dari kebudayaan dan menjadi dasar dari segenap wujud kebudayaan. Di samping itu, nilai-nilai kebudayaan diwujudkan dalam bentuk tata hidup yang merupakan kegiatan manusia yang mencerminkan nilai budaya yang dikandungnya. Nilai budaya bersifat abstrak hanya dapat ditangkap oleh akal budi manusia.

Soekanto (1990, hlm. 171) yang menyatakan bahwa masyarakat adalah orang yang hidup bersama yang menghasilkan kebudayaan. Oleh sebab itu, kebudayaan yang ada dalam masyarakat menjadi identitas dan tata cara hidup mereka. Berbagai masalah tentang kepemudaan sangatlah banyak. Dalam hal ini, Tilaar (dalam Abdullah, 1994, hlm. 10) menyatakan bahwa: "Masalah kepemudaan hendaknya jangan dianggap sebagai suatu gejala yang aneh yang terpaksa harus ada. Kepemudaan haruslah dilihat sebagai bagian dari kehidupan yang mempunyai peranan dan kewajiban sendiri."

Pemuda dengan berbagai masalahnya, harus diarahkan pada sesuatu yang bernilai positif. Hal itu tidak adakn mengubah pandangannya terhadap sambatan sebagai civic culture yang perlu dipertahankan. Abdullah (1994, hlm. 1) menyatakan bahwa: "Pemuda adalah konsep yang sering diberati oleh nilai. Hal ini karena keduanya bukanlah semata-mata istilah ilmiah tetapi pengertian ideologis atau kultural. Pemuda sebagai harapan bangsa, pemuda harus dibina. Semua itu memperlihatkan saratnya nilai-nilai yang melekat pada kata pemuda."

Untuk menghadapi tantangan global sebagaimana tersebut di atas, maka perlunya menjaga karakter pemuda saat ini. Karakter yang diharapkan yaitu sesuai dengan dasar negara kita yaitu Pancasila. Sebagaimana disebutkan di atas bahwa Pancasila bisa diambil intinya yaitu gotong royong, maka dapat disimpulkan bahwa pemuda hendaknya memiliki jiwa semangat gotong royong. Soekanto (1990, hlm. 193) bahwa: Pada umumnya generasi muda dianggap sebagai individu yang cepat menerima unsur-unsur kebudayaan asing yang masuk melalui proses akulturasi. Sebaliknya, generasi tua dianggap sebagai orang-orang yang sukar menerima unsur baru. Hal ini disebabkan oleh norma-norma tradisional yang sudah mendarah daging dan menjiwai (sudah internalized). Sebaliknya belum menetapnya unsur-unsur tradisional dalam jiwa generasi muda, menyebabkan mereka lebih mudah menerima unsur baru yang kemungkinan besar dapat mengubah kehidupan mereka.

Pemuda yang sedang belajar dalam pendidikan formal, implikasinya kepada masyarakat ialah seperti yang diungkapkan oleh Ki Hajar Dewantoro dalam Tilaar (1999, hlm. 68), mengatakan bahwa: "Kebudayaan tidak dapat dipisahkan dari pendidikan, bahkan kebudayaan merupakan alas atau dasar pendidikan. Bukan hanya dialaskan kepada suatu aspek kebudayaan yaitu aspek intelektual, tetapi kebudayaan sebagai keseluruhan. Pemuda yang tidak memiliki tingkah laku baik, bukan 
berarti pendidikan di sekolahnya gagal. Budaya dalam masyarakat juga mempengaruhi pola pikir dan tingkah laku. Pendidikan dan kebudayaan merupakan dua hal yang saling melengkapi.

Kebudayaan yang menjadi alas pendidikan haruslah bersifat kebangsaan. Dengan demikian, kebudayaan yang dimaksud adalah kebudayaan yang nyata yaitu budaya yang hidup di dalam masyarakat Indonesia. Sedangkan pendidikan mempunyai arah untuk mewujudkan keperluan perikehidupan dari seluruh aspek kehidupan manusia dan arah tujuan pendidikan untuk mengangkat derajat dan harkat manusia. Sambatan merupakan civic culture yang dapat membantu pemuda membentuk watak dan karakter Pancasila sebagai perwujudan civic disposition.

Menurut penulis sendiri bahwa pengertian gotong royong adalah suatu kegiatan yang dilakukan secara bersama-sama dan bersifat suka rela agar kegiatan yang dikerjakan dapat berjalan dengan lancar, mudah dan ringan. Dengan demikian, ada keikhlasan dan kesadaran untuk saling membantu demi terselesaikannya pekerjaan. Adanya sebuah kerja sama yang menuntut masyarakat untuk bertanggung jawab dalam bermasyarakat. Seperti yang dikemukakan oleh Soekanto (1990, hlm. 72) bahwa kerja sama dimaksudkan sebagai suatu usaha bersama antara orang perorangan atau kelompok manusia untuk mencapai satu atau beberapa tujuan bersama.

QS Al-Maidah ayat 2 yang artinya “.....Dan tolong menolonglah kamu dalam (mengerjakan) kebajikan dan taqwa, dan jangan tolong menolong dalam berbuat dosa dan pelanggaran. Kemudian hadis nasihat yang disebut diatas menjelaskan secara lebih terperinci gambaran bentuk tolong menolong dalam mengerjakan kebajikan dan takwa dengan kata-kata. Dalam Muhammad Ali Quthb (2007, hlm. 86) menyatakan bahwa bentuk persaudaraan yang merupakan dasar dibangunnya sebuah bangunan "tolong menolong" yang berdiri tegak. Penulis yakin bahwa firman Allah QS Al-Maidah ayat 2 tersebut tidak hanya berlaku bagi muslim saja.

Gotong royong dan kerukunan adalah nilai-nilai seperti yang ditemukan dalam tradisi bangsa Indonesia berasal dari pandangan hubungan manusia dengan sesamanya. Nilai dalam sistem nilai budaya Indonesia mengandung empat konsep yaitu; Manusia berada dalam komunitasnya, manusia tergantung dalam segala aspek kehidupan sesamanya, manusia harus memelihara hubungan baik dengan sesamanya, dan manusia harus bersifat adil. Keempat konsep tersebut saling berkaitan dan bergantung satu sama lain. Darminto Jatman juga menambahkan tentang peribahasa Jawa yang mencerminkan kehidupan sosial yaitu "Rumangsa melu anduweni, wajib melu angrungkepi, mulat sarira angrasa wani" yang artinya adalah "Solidaritas, Loyalitas, dan Toleransi ini adalah partisipasi.

Dalam Maryani (2012, hlm. 7) menguraikan berbagai karakteristik sambatan sebagai berikut: a. Sambatan tidak identik dengan kerja bakti, kerja bakti dengan sambatan keduanya berbeda dalam hal kepentingan, bahwa kerja bakti dilakukan untuk kepentingan orang banyak/ umum sedangkan sambatan dilakukan untuk kepentingan perseorangan/ keluarga, b. Kerja dilakukan untuk kepentingan individu/ keluarga tertentu. Sambatan bertujuan untuk membantu individu/keluarga tertentu didalam masyarakat. Hal tersebut dikarenakan sambatan merupakan bentuk dari kegiatan tolong-menolong, yang mana dalam pelaksanaan kegiatanya dilakukan dengan ikhlas karena ingin membantu, c. Dalam kegitan sambatan dapat dikatakan tidak ada upah bagi yang ikut dalam pelaksanaan kegiatan sambatan, hal tersebut menunjukkan bahwa sambatan merupakan kegiatan yang murni untuk membantu orang yang meminta tolong, $d$. Sambatan itu sendiri digerakkan oleh asas 
timbal balik, yang artinya, siapa yang pernah menolong tentu akan menerima pertolongan balik dari pihak yang ditolonganya. Dengan asas ini maka tolong-menolong dapat dikategorikan sebagai jenis pertukaran (exchange).

Simpulannya bahwa selain sebagai pengikat kesatuan dan persatuan di dalam masyarakat, kegiatan tolong-menolong juga menghindarkan masyarakat pada perpecahan. Sehingga untuk menjaga kerukunan dalam masyarakat, masyarakat perlu mewujudkan kerukunan tersebut salah satunya dengan cara melakukan kegiatan-kegiatan dengan bentuk kerja sama maupun saling tolong menolong. Desain Induk Pembangunan Karakter Bangsa (2010, hlm. 7) karakter bangsa adalah: "Kualitas perilaku kolektif kebangsaan yang unik-unik tercermin dalam kesadaran, pemahaman, rasa, karsa, dan perilaku berbangsa dan bernegara dari hasil olah pikir, olah hati, olah rasa dan karsa, serta olah raga seseorang atau sekelompok orang."

Pendidikan karakter adalah sebuah konsep yang dicanangkan pemerintah dalam pendidikan. Sejalan dengan hal tersebut, Berdasarkan Permendiknas No. 22 Tahun 2006 (dalam Winarno, 2013, hlm. 18) bahwa: "Pendidikan Kewarganegaraan diartikan sebagai mata pelajaran yang memfokuskan pada pembentukan warga negara yang memahami dan mampu melaksanakan hak-hak dan kewajibannya untuk menjadi warga negara Indonesia yang cerdas, terampil, dan berkarakter yang diamanatkan oleh Pancasila dan UUD 1945."

Berdasarkan pendapat-pendapat di atas, karakter bangsa dimaknai sebagai ciri-ciri kepribadian yang relatif tetap, gaya hidup yang khas, cara berpikir, bersikap dan berperilaku sesuai dengan nilai-nilai luhur yang bersumber dari budaya bangsa Indonesia yang dijiwai oleh nilai-nilai Pancasila dan UUD 1945 dalam rangka membina kepribadian generasi muda. Oleh karena itu, perlu ada pembangunan karakter bangsa. Warga negara yang berkarakter dalam hal ini ialah karakter yang sesuai dengan
Pancasila dan UUD 1945. Menunjuk pada Pancasila yang terdiri dari 5 sila, apabila diperas menjadi satu yaitu gotong royong. Karakter gotong royong menjadi hal utama dalam kehidupan bermasyarakat. Sejalan dengan hal tersebut, Winarno (2013, hlm. 19) menyatakan bahwa: Pendidikan Kewarganegaraan memiliki tiga fungsi pokok sebagai wahana pengembangan warga negara demokratis, yakni mengembangkan kecerdasan warga negara (civic intellegence), membina tanggung jawab warga negara (civic responsibility) dan mendorong partisipasi warga negara (civic participation).

Civic responsibility dan civic participation merupakan dua hal utama dalam penelitian ini. Membina tanggung jawab warga negara sebagai masyarakat yang memiliki tanggung jawab dalam kehidupan bersama. Hidup berdampingan dalam masyarakat banyak diperlukan keterampilan dan keseimbangan dalam berpikir dan bertindak. Sebab itu, ketiga ranah tadi merupakan hal yang penting untuk pengembangan karakter terutama pemuda. Ketika tanggung jawab warga negara tinggi, maka pada akhirnya juga akan mendorong partisipasi warga negara dalam kegiatan yang lain. Selain ketiga ranah tersebut, hal yang berkaitan dengan pendidikan karakter ialah tiga ranah yang dikemukakan oleh Branson (dalam Winarno, 2013, hlm. 19) yaitu pengetahuan kewarganegaraan (civic knowledge), keterampilan kewarganegaraan (civic skill), karakter kewarganegaraan (civic dispositions). Keterampilan dan karakter kewarganegaraan adalah ranah yang berkaitan dengan penelitian ini.

Aristoteles dalam Lickona (2012, hlm. 81) mendefinisikan karakter yang baik sebagai kehidupan dengan melakukan tindakan-tindakan yang benar sehubungan dengan diri seseorang dan orang lain. Sedangkan, menurut Michael Novak, bahwa karakter adalah campuran kompatibel dari seluruh kebaikan yang diidentifikasi oleh tradisi religius, cerita sastra, 
kaum bijaksana, dan kumpulan orang berakal sehat yang ada dalam sejarah. Dari kedua filsuf tersebut, Lickona (2012, hlm. 82) mengatakan bahwa, karakter yang baik terdiri dari mengetahui hal yang baik, menginginkan hal yang baik, dan melakukan hal yang baik. Kebiasaan dalam cara berpikir, kebiasaan dalam hati, dan kebiasaan dalam tindakan. Ketiga hal ini diperlukan untuk mengarahkan kehidupan moral, membentuk kedewasaan moral.

Karakter yang terdapat dalam tradisi sambatan adalah semangat gotong royong dan tolong-menolong untuk kepentingan pribadi maupun kepentingan umum. Membangun rasa peduli terhadap sesama dan tentu untuk menjaga keutuhan bangsa dan negara. Sebab itu, pemuda sebagai titik tengah yang berada antara kaum tua dan kaum muda berperan penting untuk belajar mempertahankan dan belajar memberikan contoh yang baik kepada generasi selanjutnya.

Semangat gotong royong dan tolongmenolong adalah inti dari kebersamaan dalam hidup bermasyarakat. Kepedulian terhadap sesama merupakan karakter penting dalam hidup dalam lingkungan yang sama. Hal yang diharapkan tentu mempunyai pengaruh positif terhadap segala tindakan. Mangunhardjana (1986, hlm. 29) bahwa: Pemuda mampu menciptakan dan membina kebersamaan dan kerja sama dengan orang lain sebagai tempat untuk mengembangkan diri dan mencapai tugas pekerjaan bersama, dalam semangat setia kawan dan Bhinneka Tunggal Ika.

Karakter gotong royong, kerja sama dan tolong-menolong tidak lepas dari fitrah manusia yang pada dasarnya tidak dapat hidup sendiri. Manusia selalu membutuhkan orang lain dalam kehidupan bermasyarakat. Soekanto (1990, hlm. 74) bahwa: Pandangan hidup bahwa seseorang tidak mungkin hidup sendiri tanpa kerja sama dengan orang lain. Pandangan hidup demikian ditingkatkan dalam taraf kemasyarakatan, sehingga gotong royong seringkali diterapkan untuk menyelenggarakan suatu kepentingan.
Hubungan antara kehidupan bermasyarakat dengan gotong royong sebagai kebudayaan ialah sesuai pernyataan Herskovits dan Malinowski (dalam Soekanto, 1990, hlm. 171) mengemukakan bahwa: "Cultural Determinism berarti segala sesuatu yang terdapat didalam masyarakat ditentukan adanya oleh kebudayaan yang dimiliki oleh masyarakat itu. Kemudian Herskovits memandang kebudayaan sebagai sesuatu yang super-organic, karena kebudayaan yang turun-temurun dari generasi ke generasi tetap hidup terus."

Antara masyarakat, kebudayaan dan kepribadian mempunyai hubungan yang sangat erat. Seperti diungkapkan Newcomb (dalam Soekanto, 1990, hlm. 185), yaitu bahwa: "Kepribadian merupakan organisasi sikap-sikap (predispositions) yang dimiliki seseorang sebagai latar belakang seseorang untuk berbuat, mengetahui, berpikir dan merasakan secara khususnya apabila dia berhubungan dengan orang lain atau menanggapi suatu keadaan. Karena kepribadian merupakan abstraksi individu dan kelakuannya sebagaimana halnya dengan masyarakat dan kebudayaan, maka ketiga aspek tersebut mempunyai hubungan yang saling pengaruh-mempengaruhi satu dengan lainnya"

Interaksi yang terjadi dalam masyarakat merupakan proses pendidikan yang menjadikan pemuda itu lebih berkualitas dan berkarakter. Sesuai pernyataan Soekanto (1990, hlm. 442) bahwa didalam proses interaksi yang melibatkan anak dan remaja, terjadi proses sosialisasi yang bertujuan agar pihak yang dididik mematuhi kaidah-kaidah dan nilai-nilai yang berlaku dan dianut oleh masyarakat. Tujuan akhir adalah agar manusia bersikap dan bertindak sesuai dengan kaidah-kaidah dan nilai-nilai yang berlaku serta agar yang bersangkutan menghargainya."

Berdasarkan beberapa hal di atas, maka sangat penting pelestarian tradisi gotong royong bagi pemuda melalui tradisi "sambatan" yang 
dilakukan di desa Jogorogo. Untuk melestarikan budaya bangsa yang dijadikan pondasi kebersamaan dalam bermasyarakat, berbangsa dan bernegara. Terutama pemuda sebagai penerus bangsa seharusnya mempunyai watak dan keterampilan berwarganegara yang sesuai dengan karakter Pancasila. Sambatan sebagai contoh dalam bergotong royong merupakan wujud keterampilan berwarga negara yang baik. Penelitian ini bertujuan untuk memperoleh gambaran bagaimana peran pemuda dalam kegiatan kemasyarakatan dan pelaksanaan tradisi sambatan di desa Jogorogo. Manfaat penelitian dari segi teori diharapkan hasil penelitian ini dapat memberikan gambaran dan mengembangkan ilmu serta pengetahuan yang berhubungan dengan peran pemuda di masyarakat dalam melestarikan budaya gotong royong. Manfaat/ signifikansi dari segi kebijakan dan praktik yaitu, diharapkan pemuda di Indonesia dapat kembali semangat untuk melestarikan budaya gotong royong dan mengimplementasikan Undang-Undang nomor 40 tahun 2009. Manfaat/ signifikansi dari segi isu serta aksi sosial yaitu diharapkan penelitian ini sangat bermanfaat bagi peneliti guna menambah wawasan keilmuan peneliti di bidang kepemudaan. Adanya penelitian dibidang kepemudaan ini, diharapkan peneliti maupun masyarakat dapat dengan maksimal menerapkan dan melestarikan tradisi gotong royong.

\section{METODE PENELITIAN}

Penelitian ini menggunakan pendekatan kualitatif. Metode yang digunakan adalah metode deskriptif yang berusaha menemukan berbagai informasi dengan melakukan kajian analitis kritis terhadap informasi atau data yang diperoleh. Penelitian ini dilaksanakan di desa Jogorogo, kecamatan Jogorogo, kabupaten Ngawi, Provinsi Jawa Timur. Informan adalah Perangkat desa, pengurus karang taruna, dan tokoh masyarakat. Pertimbangan pemilihan informan adalah karena masyarakat menjadi pengamat dan pelaksana tradisi sambatan. Instrumen dalam penelitian ini yaitu peneliti secara utuh terlibat pada aktivitas informan didukung oleh pedoman wawancara, dan pertanyaan-pertanyaan tambahan. Teknik pengumpulan data dilakukan dengan wawancara, observasi, dan studi dokumentasi. Teknik analisa data dilakukan dengan reduksi data, penyajian data dan penarikan kesimpulan/ verifikasi data. Data yang diperoleh kemudian dianalisis menggunakan teknik analisis data seperti yang dikemukakan oleh Miles dan Huberman (1992, hlm. 16-18) yaitu dengan langkah-langkah: reduksi data, penyajian data, dan menarik kesimpulan/verifikasi.

\section{HASIL DAN PEMBAHASAN}

Bagian ini akan mendeskripsikan temuan penelitian mengenai peran pemuda dalam kemasyarakatan terutama tradisi sambatan dalam rangka pembentukan karakter. Pemuda yang dimaksud adalah seluruh pemuda yang ada di desa Jogorogo yang aktif dalam kegiatan kemasyarakatan tergabung dalam karang taruna. Dan karakter yag dimaksud adalah karakter yang sesuai dengan Pancasila yaitu gotong royong. Dalam masyarakat Jogorogo istilah gotong royong dinamakan tradisi sambatan.

\section{Peran Pemuda Dalam Tradisi Sambatan}

Menurut (PY) bahwa peran pemuda sangat penting dalam kegiatan kemasyarakatan di desa Jogorogo. Pengalaman orang tua menjadi hal yang penting dalam memberikan gambaran kepada pemuda untuk bersikap dan bertindak. Oleh karena itu, orang yang lebih tua harus bisa "ngemong" atau memberi contoh yang baik kepada pemuda. Menurut (DA) bahwa peran pemuda dalam kegiatan kemasyarakatan sangat penting. Yang menjadi penting ialah pada intinya pemuda sebagai penerus dalam segala hal. Dalam karang taruna sangat membutuhkan pemuda sebagai pelaku estafet regenerasi kegiatan kemasyarakatan. 
Tentunya yang diharapkan adalah segala sesuatu yang bersifat membangun. Menurut (BS) bahwa karang taruna itu pada dasarnya menciptakan sebuah kegiatan yang intinya untuk pembentukan karakter. Dengan kegiatan positif, secara tidak langsung juga akan menghasilkan hal yang positif. Sehingga terdapat pergerakan anak-anak muda ke arah yang lebih baik. Karang taruna membentuk suatu kegiatan yang jelas yang dapat menjadi fokus kegiatan pemuda untuk perkembangannya yang lebih baik.

Menurut (BM) bahwa karang taruna sebagai organisasi atau perkumpulan sebaiknya bisa menjadi wadah atau media dalam pembentukan karakter. (DS) bahwa "Peranan pemuda sebenarnya sangat penting dalam masyarakat, karena tenaganya sangat dibutuhkan selain itu juga bisa memberikan pengalaman kepada mereka tentang bagaimana hidup bermasyarakat.

Dari beberapa wawancara diatas dapat diambil kesimpulan bahwa peran pemuda dalam tradisi sambatan adalah sebagai penerus tradisi ini untuk generasi selanjutnya, sebagai upaya dalam membentuk karakter yang baik sesuai dengan karakter Pancasila, sebagai wujud pengabdian kepada masyarakat dalam posisinya sebagai anggota masyarakat, sebagai bagian dari upaya menjaga kerukunan dan kebersamaan dalam masyarakat, dan sebagai poin penting yang dapat menunjukkan bahwa masyarakat terjalin dengan aktif dan damai.

Bagi kaum muda, kegiatan kemasyarakatan sangatlah penting sebenarnya bagi kelangsungan hidup dalam bermasyarakat. Pemuda dalam masyarakat menjadi peran utama dalam meneruskan kembali tradisi yang ada. Betapa pentingnya peran pemuda dalam meneruskan kembali segala sesuatu yang ada dalam masyarakat. Pemuda berada ditengahtengah generasi antara generasi tua dan generasi yang ada dibawahnya. Sehingga harusnya bisa menjadi penyeimbang diantara keduanya.

\section{Bentuk Kegiatan Tradisi Sambatan}

Menurut (PY) bahwa kegiatan nonprogram karang taruna yang mencerminkan sambatan adalah berupa sinoman yaitu bantubantu di tempat orang hajatan, kerja bakti di lingkungan masyarakat, membersihkan makam dengan pemberitahuan ketua RT, bantu-bantu pada saat pengajian rutin desa, ketika ada musibah dalam tetangga dengan otomatis mereka datang untuk menyiapkan keperluan. Dalam hal ini tetangga yang paling dekatlah yang berperan utama. Pemberitahuan sambatan kepada masyarakat ada tradisi sendiri yaitu dengan istilah "Gethok Tular" maksudnya adalah pemberitahuan dari mulut ke mulut langsung mendatangi rumah ke rumah meskipun pada zaman sekarang sudah ada alat komunikasi canggih akan tetapi hal itu menjadi kepuasan tersendiri dengan mendatangi ke rumah-rumah.

Menurut (DA) bahwa bentuk kegiatan karang taruna yang sudah rutin dijalankan selama ini adalah kegiatan sinoman, kerja bakti, kegiatan formal atau pengajian, dalam musibah kematian. Menurut (BS) bahwa kegiatan gotong royong dalam karang taruna adalah bersih desa, muslimat NU, karnaval 17 Agustus, pawai buah. Kegiatan bersih desa kerja bakti dalam lingkungan itu sudah otomatis menjadi rutinitas.

(AM) menambahkan kegiatan sambatan dalam masyarakat adalah kerja bakti bersihbersih lingkungan, sinoman atau kegiatan dalam hajatan warga, dan sambatan bangun rumah yang berupa "ngecor", taziah atau tetangga yang mengalami musibah kematian. Menurut (DS) bahwa sambatan dalam mendirikan rumah atas dasar peduli dan sukarela serta kerja sama yang tinggi, gugur gunung istilahnya membersihkan makam pada saat akan masuk bulan suro, lebaran dan hari-hari tertentu.

Berdasarkan wawancara dengan (AM) bahwa sambatan itu adalah memberi bantuan yang tanpa komando sudah otomatis memberi bantuan, sudah datang sendiri memberi bantuan sebisa yang dia lakukan. 


\section{Upaya dalam Mengatasi Kendala Pelestarian Sambatan}

Menurut (PY) upaya yang dilakukan untuk mengajak pemuda untuk berpartisipasi dalam kegiatan kemasyarakatan adalah dengan merangkul dan mengajak mereka, menumbuhkan rasa antusias pemuda, yang pada akhirnya mereka merasa diibutuhkan sehingga timbul rasa kesadaran dalam hidup bermasyarakat. Istilah "mengorangkan" adalah menganggap mereka ada dan sangat dibutuhkan tenaganya. Dalam kegiatan internal karang taruna, ada beberapa kegiatan yang diusahakan untuk memberikan keterampilan dasar pada pemuda diantaranya adalah pelatihan pembuatan jamur, pelatihan ternak lele, dan yang akan diusahakan adalah pelatihan komputer dan kursus jahit.

Menurut (DA) semuanya juga tergantung golongan tuanya. Kalau yang tua senantiasa mengajak dan terbuka kepada pemuda, maka kemungkinan pemuda yang malu-malu akan tertarik untuk ikut. Mungkin bisa dikatakan pemuda sekarang sedikit manja, jadi masih ada yang mengandalkan ajakan, dan hal itu perlu diberi pengertian bahwa kita semua sangat membutuhkan tenaganya, yang dimaksud adalah tenaga pemuda untuk ikut dalam kegiatan kemasyarakatan. Sehingga mereka benar-benar sadar bahwa dirinya sangat berperan dalam masyarakat. Menurut (ASW) bahwa kegiatan karang taruna lebih bagus apabila difokuskan ke arah produktif seperti pelatihan dan penyuluhan.

Menurut (DS) pemuda saat ini belum aktif dalam kegiatan karang taruna. Mungkin yang dialami anak-anak sekolah untuk mengikuti kegiatan karang taruna masih terbentur rasa malu. Menurut (AS) adalah dengan memaksimalkan organisasi-organisasi yang ada dalam masyarakat. Paguyuban peladen/ sinoman adalah salah satu perkumpulan untuk menghidupkan kembali tradisi sambatan itu. Lebih besar lagi yaitu dengan karang taruna, yang harus memiliki program-program yang terkait dengan peduli.

\section{Kaitan Keikutsertaan Pemuda dalam Sambatan dengan Karakter}

Menurut (BS) bahwakaitan antara keterlibatan pemuda dalam karang taruna dengan pembentukan karakter masyarakat adalah sangat terlihat perbedaannya. Pemuda yang mengikuti kegiatan karang taruna dengan pemuda yang tidak mengikuti itu memiliki perbedaan yang mencolok salah satunya yaitu terdapat pada fokus tindakannya berupa kegiatan yang mempunyai visi dan tujuan yang jelas. Selain itu juga terlihat dari cara dia berkomunikasi. Menurut (PY) sanksi apabila pemuda tidak mengikuti sambatan sementara ini belum ada, apabila terjadi hal itu selama ini hanya sanksi yang berasal dari diri sendiri saja. Misalnya, merasa tidak enak atau sungkan apabila bertemu dengan orang lain.

Menurut (PY) selain karakter tanggung jawab, adalah karakter mandiri. Sementara ini masih dalam proses untuk pelaksanaan pelatihan kewirausahaan. Pelatihan jahit, komputer, ternak lele, pembuatan jamur. Sehingga, pemuda lebih diprioritaskan untuk mandiri di desanya sendiri daripada harus pergi jauh-jauh keluar kota demi mencari rejeki. Menurut (DA) karakter yang diharapkan dalam kegiatan kebersamaan dalam masyarakat adalah adanya kesadaran bahwa untuk kedepannya kita tidak hidup sendiri. Kita menolong orang lain itu supaya Allah memberikan balasan kepada kita tentang hal yang baik juga. Jadi, menolong orang itu jangan semata-mata pamrih. Menurut (HF) ada hubungannya antara keterlibatan pemuda dalam karang taruna dengan karakter. Hubungannya adalah keegoisan individu dalam memenuhi kebutuhan masing-masing. Maksudnya adalah ketika pemuda akan ikut dalam perkumpulan karang taruna, mereka lebih memilih untung yang didapat dalam perkumpulan itu. Menurut (BS) karakter yang diharapkan adalah pemuda Jogorogo mempunyai jiwa rukun, kebersamaan dalam kegiatan yang positif dan kegiatan yang 
produktif. Selain itu juga adanya jiwa mandiri dalam menghadapi semua persoalan. Menurut (BS) ketertarikan pemuda dalam mengikuti kegiatan karang taruna yang bersifat produktif sangat tinggi bahkan tidak tertampung." Hal itu menandakan bahwa semakin banyak pelatihan yang dilakukan maka akan semakin banyak pula pemuda yang antusias mengikuti pelatihan. Menurut (BS) kaitan antara keterlibatan pemuda dalam karang taruna dengan pembentukan karakter masyarakat adalah sangat terlihat perbedaannya. Pemuda yang mengikuti kegiatan karang taruna dengan pemuda yang tidak mengikuti itu memiliki perbedaan yang mencolok salah satunya yaitu terdapat pada fokus tindakannya berupa kegiatan yang mempunyai visi dan tujuan yang jelas. Menurut (AM) sambatan itu adalah memberi bantuan yang tanpa komando sudah otomatis memberi bantuan, sudah datang sendiri memberi bantuan sebisa yang dia lakukan.

Menurut (AM) tradisi itu muncul karena ada kebiasaan yang bersamaan, saling merasakan, saling menghormati dan tepo seliro. Tidak ada sanksi bagi warga yang tidak ikut andil dalam tradisi sambatan. Mungkin sedikit sanksi sosial dari norma kebiasaan yang hanya bisa dirasakan oleh orang yang sensitif terhadap perilaku orang lain. Merasa tidak enak atau pakewuh apabila lain waktu bertemu dengan orang lain bersama orang yang lebih tua. Kebiasaan di desa bahwa pemberitahuan yang dilakukan oleh pemimpin itu merupakan suatu perintah yang harus dijalankan. Seperti halnya sambatan, seharusnya tidak ada komando dari atasan maka masyarakat sudah otomatis melakukannya dan apabila ada perintah, maka hal itu menjadi suatu keharusan.

Menurut (DS) tingkat kepedulian masyarakat lebih didominasi oleh pemuda yang sudah berkeluarga karena tingkat kedewasaannya. Cara pandang dan peduli terhadap lingkungan menjadi tinggi ketika pemuda itu sudah berkeluarga dan mempunyai satu orang anak yang mungkin masih balita. Karakter pemuda yang diharapkan saat ini adalah sopan santun, karena saat ini sudah sangat berkurang. Saling tolong menolong dan peduli karena saat ini sudah banyak orang yang mementingkan urusannya sendiri. Pemuda ingin dipuji, sebenarnya mereka mengalami krisis prestasi akan tetapi salah jalan. Pengen dihargai orang tapi tidak mau menghargai. Menurut (AS) sambatan itu adalah kearifan lokal yang harus dipertahankan karena sambatan ini adalah tradisi turun-temurun dari nenek moyang.

\section{Upaya Masyarakat dalam Meningkatkan Apresiasi Pemuda}

Menurut (DA) ketika pemuda kita hargai keberadaannya, insyaallah mereka juga akan mendengarkan ajakan kita. Istilahnya dengan cara pelan-pelan kita mengajak mereka. Pemuda jangan selalu disalahkan, jangan membuat mereka merasa tertekan karena mereka sangat dibutuhkan dalam masyarakat. Mereka juga dalam proses pembentukan karakter, sehingga yang namanya proses perlu diluruskan kembali. Pembentukan karakter dalam masyarakat sangat penting karena itu juga wujud nyata dari pendidikan yang diperoleh dalam sekolah.

Menurut (DA) pelatihan dan penyuluhan bertujuan untuk memberikan pengetahuan dan keterampilan supaya bisa menghasilkan uang. Apabila sudah mandiri maka kendala ekonomi tidak menjadi masalah atau alasan untuk tidak membangun masyarakat. Menurut (BS) bentuk kegiatan yang akan berjalan adalah kegiatan yang sifatnya membentuk atau melatih keterampilan pemuda, salah satunya adalah budidaya jamur tiram. Sehingga akan membentuk lapangan pekerjaan dan karang taruna menjadi eksis apabila kegiatannya itu tidak hanya kumpul, tetapi juga mengarah kepada lapangan pekerjaan. Hal yang harus diperhatikan adalah kemandirian pemuda atau kehidupan ekonominya. Pemuda akan tertarik apabila ada kegiatan yang produktif atau 
menghasilkan uang karena akhir-akhir ini ekonomi negara kita semakin tidak jelas dan bahaya apabila pemuda menjadi sasaran dan tidak bisa mengontrol emosinya. Karena itu, kehidupan ekonominya harus dibangun dan diperkuat untuk membentuk karakter kemandiriannya. Menurut (BS) model pendidikan karakter di masyarakat mengikuti atau menyesuaikan karakter atau kepribadian masing-masing individu.

Menurut (DS) upaya yang dilakukan selama ini adalah dengan memberikan pengertian, diajak, dan diberi gambaran bahwa kegiatan karang taruna itu positif. Rasa malu yang dimiliki anak sekolah itu cenderung malu yang takut salah. Hal yang penting dan perlu diarahkan adalah dalam bidang agama karena pondasi pertama yang diharapkan adalah kekuatan spiritual. Menurut (AS) pemuda diberi wawasan tentang pengalaman orang lain sehingga bisa mengambil nilai-nilai positif dari pengalaman orang lain tersebut. Yang perlu diperbaiki dalam pembentukan karakter selama ini adalah keteladanan. Menurut (S) permasalahan pemuda pada saat ini adalah faktor ekonomi terkait dengan modal, yang mengarahkan juga masih minim.

Peran pemuda yang disebutkan dalam Undang-Undang Republik Indonesia nomor 40 tahun 2009 pasal 16 bahwa, "Pemuda berperan aktif sebagai kekuatan moral, kontrol sosial, dan agen perubahan dalam segala aspek pembangunan nasional. Peran yang harus diembannya ini haruslah menjadi poin penting dalam kehidupan sehari-harinya. Tentunya yang diwariskan ini adalah sesuatu yang baik.

Sebagai kekuatan moral, pemuda dalam hal ini adalah sebagai subjek pelaksanaan tradisi sambatan. Moral yang ada di masyarakat harus diperkuat dengan karakter yang baik dan pemuda harus menjadi pioner utama sebagai komunitas yang mempunyai kekuatan yang baik. Pemuda berperan juga dalam kontrol sosial, apa yang terjadi di masyarakat baik ataupun buruk, semua harus tetap berada dalam koridor yang ditentukan yaitu karakter Pancasila. Segala keburukan dan perubahan sosial yang terjadi harus dikontrol dan diawasi. Dalam hal ini tradisi sambatan sebagai media pemuda dalam mengontrol apa yang terjadi dalam masyarakat. Terakhir adalah sebagai agen perubahan dalam segala aspek pembangunan nasional. Perubahan yang diharapkan adalah perubahan ke arah yang lebih baik. Tentunya pemuda juga harus mampu menyeimbangkan perubahan sosial dengan mempertahankan tradisi yang ada dalam masyarakat. Sebagai pelopor dan pembaharu dalam perubahan ke arah yang lebih baik.

Tidak serta merta pemuda sebagai subjek dalam pelestarian tradisi sambatan. Peran golongan tua juga berperan sebagai pembina atau yang mengarahkan supaya tidak keluar dari jalur. Pendidikan karakter sebenarnya sudah lama dicanangkan pemerintah dalam dunia pendidikan. Akan tetapi, pelaksanaannya dapat dikatakan setengah-setengah apabila tidak diimbangi dengan kondisi lingkungan yang positif. Pelaksanaan sambatan tidak memerlukan proses yang lama atau ribet. Dengan hanya bermodalkan pemberitahuan dari mulut ke mulut saja semua orang sudah paham.

Meskipun tidak sesuai dengan apa yang tercantum pada Undang-Undang Tentang Kepemudaan, namun masyarakat Jogorogo yang berumur diatas 30 tahun tetap berkecimpung dalam kegiatan kepemudaan. Hal itu untuk membantu berjalannya kegiatan dan membantu pemuda dalam melaksanakan kegiatan. Oleh karena itu, peran pemuda dalam kemasyarakatan dapat disimpulkan yaitu sebagai berikut: Generasi penerus tradisi, mempelajari dan memahami tradisi dan kebiasaan dari kaum tua, menerapkan dalam kehidupan sehari-hari sesama generasinya, mendampingi generasi selanjutnya dalam proses pemahaman, pelaksanaan, dan evaluasi tradisi sambatan dan yang terakhir, dan memberikan pengalaman 
tradisi ini kepada generasi selanjutnya. Kesimpulan tersebut dapat mengerucut pada ciri-ciri karakter yang diungkapkan oleh Budimansyah dan Suryadi (2008, hlm. 61) ciriciri karakter privat seperti: tanggung jawab moral, disiplin diri dan penghargaan terhadap harkat dan martabat manusia dari setiap individu. Sedangkan ciri-ciri karakter publik yaitu kepedulian sebagai warga negara, kesopanan, mengindahkan aturan main (rule of law), berpikir kritis, dan kemauan untuk mendengar, bernegosiasi dan berkompromi.

Penulis menemukan penelitian serupa yang menghasilkan temuan berupa perbedaan antara sambatan dengan kerja bhakti. Dalam makalah seminar yang ditulis oleh Maryani (2012, hlm. 7) menguraikan berbagai karakteristik sambatan sebagai berikut: Sambatan tidak identik dengan kerja bakti, kerja bakti dengan sambatan keduanya berbeda dalam hal kepentingan, bahwa kerja bakti dilakukan untuk kepentingan orang banyak/ umum sedangkan sambatan dilakukan untuk kepentingan perseorangan/ keluarga. Sambatan bertujuan untuk membantu individu/keluarga tertentu di dalam masyarakat. Hal tersebut dikarenakan sambatan merupakan bentuk dari kegiatan tolong menolong. Dalam kegiatan sambatan dapat dikatakan tidak ada upah bagi yang ikut dalam pelaksanaan kegiatan sambatan, hal tersebut menunjukkan bahwa sambatan merupakan kegiatan yang murni untuk membantu orang yang meminta tolong. Sambatan itu sendiri digerakkan oleh asas timbal balik, yang artinya, siapa yang pernah menolong tentu akan menerima pertolongan balik dari pihak yang ditolonganya. Dengan asas tersebut maka tolong-menolong dapat dikategorikan sebagai jenis pertukaran (exchange).

Berbeda dengan penemuan penelitian yang dilakukan oleh Sri Maryani tersebut. Dalam penelitian ini, penulis menyimpulkan bahwa pelaksanaan tradisi sambatan dalam berbagai kegiatan bisa dijabarkan sebagai berikut: Pada hajatan warga atau disebut dengan sinoman, Kerja bakti juga tidak memerlukan pembagian kerja menurut keahlian. Kerja bakti dalam pelaksanaannya berdasarkan usia mungkin ada anak yang terlalu muda mengikuti kerja bakti ini sehingga terdapat pembagian kerja tersendiri berdasarkan umur dan kemampuannya. Tetangga yang terkena musibah dalam hal ini maksudnya adalah kematian. Pemuda langsung mengikuti arahan dari orang yang lebih tua untuk mengambil perannya. Kegiatan mendirikan rumah, dalam hal ini di zaman modern tradisi sambatan dalam mendirikan rumah masih berjalan. Ada sedikit perbedaan yang mungkin terdapat pada pelaksanaan karena model atau bentuk bangun rumah yang berbeda dengan zaman dulu. Pada saat sekarang, masih ada sambatan bangun rumah yang bangunannya terdapat lantai 2 dan selanjutnya. Sambatan dalam hal ini adalah berupa "ngecor" yaitu membantu bangun rumah dengan membawa adonan beton karena hal ini membutuhkan banyak orang dan proses yang cepat.

Dengan demikian, sangat bertentangan dengan apa yang diungkapkan oleh Sri Maryani tersebut, bahwa dalam penelitian ini sambatan identik dengan kerja bakti karena termasuk dalam kategori sambatan. Pada poin kedua bahwa sambatan hanya untuk kepentingan individu, sangat berbeda dengan hasil penelitian saya bahwa sambatan tidak hanya untuk kepentingan individu tetapi juga untuk kepentingan umum. Adanya asas timbal balik bukan merupakan sambatan. Bahwa asas timbal balik untuk kepentingan individu itu tergantung pada keikhlasan individunya. Sedangkan untuk kepentingan umum asas timbal baliknya adalah abstrak, pelaksanaannya sesuai dengan apa yang terbaik dan musyawarah.

Beberapa kegiatan yang mencerminkan gotong royong dalam masyarakat adalah: Sinoman yaitu bantu-bantu di tempat orang 
hajatan, kerja bakti bersih desa di lingkungan masyarakat, gugur gunung istilahnya membersihkan makam pada saat akan masuk bulan suro, lebaran dan hari-hari tertentu dengan pemberitahuan ketua RT, bantu-bantu pada saat pengajian rutin desa muslimat NU, ketika ada musibah kematian dalam tetangga dengan otomatis mereka datang untuk menyiapkan segala sesuatunya, karnaval 17 Agustus, pawai buah, sambatan bangun rumah yang berupa "ngecor".

Sampai saat ini, meskipun ada handphone untuk berkomunikasi, masyarakat Jogorogo masih menggunakan cara tradisional yaitu dengan "Gethok Tular" maksudnya pemberitahuan dari mulut ke mulut langsung mendatangi rumah ke rumah. Kebiasaan gethok tular dapat diambil nilai positif yaitu silaturrahmi mengunjungi orang dari rumah ke rumah, keikhlasan dan kepedulian demi terlaksananya sambatan, memastikan bahwa informasi yang diberikan dapat langsung diterima oleh yang bersangkutan. Kebiasaan gethok tular ini menjadi sistem dan cara yang dilakukan oleh masyarakat Jogorogo sehingga menjadi suatu sistem norma yang berlaku di masyarakat. Sistem norma atau aturan tersebut akan berjalan lancar dan akan terus ada apabila hal ini dilakukan oleh pemuda. Latihan dan kebiasaan akan mendarah daging pada diri pemuda dan pada akhirnya akan merasa kurang lengkap apabila gethok tular tidak dilakukan.

Sambatan sebagai budaya dan tradisi yang ada di masyarakat Jogorogo sebagai perwujudan nilai-nilai Pancasila yang pada intinya adalah gotong royong. Sambatan perlu dipertahankan dan diwariskan kepada pemuda sebagai aktor dan pihak yang meneruskannya. Pemahaman nilai-nilai perlu ditanamkan secara terus menerus, supaya terjadinya proses yang berkesinambungan. Membangun pemahaman pemuda tentang arti pentingnya hidup bermasyarakat sesuai dengan nilai-nilai Pancasila adalah kewajiban kita bersama.
Pemahaman akan muncul secara sadar pada diri pemuda ketika mereka benar-benar merasakan arti pentingnya kebersamaan.

Kaitannya dengan pembangunan karakter bangsa, ialah bahwa sambatan merupakan salah satu dasar pembentukan karakter bangsa. Karakter bangsa merupakan sikap dan perilaku warga negara yang sesuai dengan kaidah-kaidah yang berlaku di masyarakat. Kaidah-kaidah tersebut merupakan satu kesatuan yang ada dalam kehidupan masyarakat yang memiliki kekuatan tersendiri dalam menunjang keberhasilan pembangunan karakter bangsa. Karakter bangsa pula yang memberi jalan terhadap keberhasilan suatu bangsa. Karakter bangsa merupakan cerminan perilaku seseorang dalam masyarakat. Sesuai dengan pernyataan Lickona (2012, hlm. 82) mengatakan bahwa, karakter yang baik terdiri dari mengetahui hal yang baik, menginginkan hal yang baik, dan melakukan hal yang baik. Kebiasaan dalam cara berpikir, kebiasaan dalam hati, dan kebiasaan dalam tindakan. Ketiga hal ini diperlukan untuk mengarahkan suatu kehidupan moral, membentuk kedewasaan moral.

Pembangunan karakter bangsa merupakan hal yang sangat penting karena berhubungan dengan proses membina, memperbaiki, dan mewarisi warga negara tentang konsep, perilaku, dan nilai luhur budaya Indonesia yang dijiwai oleh nilai-nilai Pancasila dan UUD 1945 sehingga terinternalisasi dalam diri individu dan terbentuk warga negara yang tangguh, kompetitif, berakhlak mulia, bermoral, berbudi luhur, bertoleran, bergotong royong, berjiwa patriotik, berkembang dinamis, berorientasi iptek yang semuanya didasari oleh iman dan takwa kepada Tuhan Yang Maha Esa. Karakter yang didapat dari keikutsertaan pemuda dalam sambatan ini antara lain adalah: Kepedulian terhadap sesama, tanggung jawab atas semua yang terjadi di masyarakat, teliti dalam mengambil tindakan, dan keterampilan dalam berkomunikasi dengan orang lain. Sesuai 
dengan Desain Induk Pembangunan Karakter Bangsa (2010, hlm. 7) karakter bangsa adalah: "Kualitas perilaku kolektif kebangsaan yang unik-unik tercermin dalam kesadaran, pemahaman, rasa, karsa, dan perilaku berbangsa dan bernegara dari hasil olah pikir, olah hati, olah rasa dan karsa, serta olah raga seseorang atau sekelompok orang." Oleh karena itu, kaitan yang sangat erat antara sambatan dan pemuda adalah pemuda menjembatani proses transformasi nilai karakter Pancasila kepada generasi selanjutnya. Ketika pemuda sudah menjalani sesuai dengan karakter yang ditetapkan oleh pemerintah maka 2 dari 3 generasi sudah terselamatkan dalam memperbaiki karakter.

Upaya yang dilakukan untuk mengajak pemuda untuk berpartisipasi dalam kegiatan kemasyarakatan adalah dengan merangkul dan mengajak mereka, menumbuhkan rasa antusias pemuda, yang pada akhirnya mereka merasa diibutuhkan sehingga timbul rasa kesadaran dalam hidup bermasyarakat. Untuk memaksimalkan peran pemuda dalam kegiatan kemasyarakatan, perlu adanya upaya memberikan tanggung jawab dan tugas kepada pemuda. Sehingga pemuda itu terlibat dan memiliki rasa tanggung jawab atas tugas yang diembannya. Upaya selanjutnya adalah dengan mengajak, memberi pengertian, menciptakan budaya malu dan pakewuh apabila tidak mengikuti sambatan dan itu tidak perlu dipaksa.

Beberapa aspek penting yang perlu dipahami pemuda dalam tradisi sambatan adalah bahwa sambatan itu penting untuk meringankan beban. Menyelesaikan pekerjaan secara bersama-sama akan mempercepat terselesaikannya suatu pekerjaan. Serta beberapa manfaat lainnya yang sangat menguntungkan bagi masyarakat. Selain karakter tanggung jawab, adalah karakter kemandirian. Sementara ini masih dalam proses untuk pelaksanaan pelatihan kewirausahaan. Pelatihan jahit, komputer, ternak lele, pembuatan jamur. Sehingga, pemuda lebih diprioritaskan untuk mandiri di desanya sendiri daripada harus pergi jauh-jauh keluar kota demi mencari rejeki. Adanya pelatihan tadi dimaksudkan untuk mengurangi pengangguran, agar remaja lebih produktif dan menghasilkan karya yang bagus.

Poin penting dari beberapa informan di atas bahwa dalam upaya mengatasi kendala pelestarian sambatan adalah sebagai berikut: Secara halus memberikan pengertian kepada pemuda tentang pentingnya hidup bermasyarakat. Perbincangan melalui pertemuan formal maupun nonformal seperti yang dilakukan pemuda biasanya dalam berkumpul, Membagi tugas sesuai dengan kapasitasnya. Berkaitan dengan profesi yang dijalani, pemuda terkadang sibuk dengan profesinya. Tidak menutup kemungkinan bahwa yang harus menjadi prioritas adalah profesinya, Menganggap atau mengorangkan pemuda. Dalam hal ini untuk mengatasi pemuda yang pasif. Banyak anggapan pemuda bahwa dalam suatu kegiatan kemasyarakatan itu hanya dilakukan oleh orang tua atau golongan tua saja, menjaga sikap kita terhadap kesalahan pemuda dalam tradisi sambatan. Meminimalisir keputusan pemuda untuk tidak mengikuti sambatan. Hal ini terjadi karena banyak pemuda yang takut resiko mengikuti sambatan. Mereka malu dan takut apabila melakukan kesalahan sedikit yang ditimbulkannya, memaksimalkan organisasiorganisasi yang ada di dalam masyarakat. Paguyuban peladen/ sinoman adalah salah satu perkumpulan untuk menghidupkan kembali tradisi sambatan itu.

Upaya yang dilakukan untuk mempertahankan tradisi sambatan dengan selalu memberikan pengertian kepada pemuda bahwa keberadaannya di masyarakat sangat penting untuk membantu terselesaikannya suatu pekerjaan yang dilakukan dengan gotong royong. Pendampingan dengan selalu berdiskusi dengan pemuda mengenai hal-hal yang berkaitan dengan kejadian di masyarakat. 
Mengajak mereka kepada pokok bahasan yang membuat mereka berpikir kedepan. Membantu pemerintah dalam mewujudkan tujuan pendidikan yang sesungguhnya karena akan seimbang apabila masyarakat dan lingkungan sekitarnya juga ikut membantu pelaksanaan pendidikan karakter.

Sangat perlu untuk tetap menjaga karakter pemuda Indonesia sesuai dengan karakter Pancasila. Hubungan pemuda, masyarakat dan karakter sangatlah erat sehingga ketiganya harus dijaga. Proses yang terjadi di masyarakat merupakan proses pemuda dalam mencapai kedewasaan bermasyarakat. Interaksi yang terjadi dalam masyarakat merupakan proses pendidikan yang menjadikan pemuda itu lebih berkualitas dan berkarakter. Upaya yang dilakukan untuk mengatasi berbagai kendala dalam pelestarian tradisi sambatan adalah dengan berjalan bersama-sama mengawasi dan menuntun pemuda ke arah yang lebih baik.

Karakter yang diharapkan dalam kegiatan kebersamaan dalam masyarakat adalah adanya kesadaran bahwa untuk kedepannya kita tidak hidup sendiri. Kita menolong orang lain itu supaya Allah memberikan balasan kepada kita tentang hal yang baik juga. Jadi, menolong orang itu jangan semata-mata pamrih. Kegiatan sinoman dan sambatan tetep ada sebagai kegiatan pendamping. Selain itu, sebagai kegiatan berupa pengabdian kepada masyarakat. Karakter yang diharapkan adalah pemuda Jogorogo mempunyai jiwa rukun, kebersamaan dalam kegiatan yang positif dan kegiatan yang produktif. Adanya jiwa mandiri dalam menghadapi semua persoalan. Kesemuanya itu berawal dari kebersamaan yaitu sambatan dan gotong royong.

Kaitan antara keterlibatan pemuda dalam karang taruna dengan pembentukan karakter masyarakat adalah sangat terlihat perbedaannya. Pemuda yang mengikuti kegiatan karang taruna dengan pemuda yang tidak mengikuti itu memiliki perbedaan yang mencolok salah satunya yaitu terdapat pada fokus tindakannya berupa kegiatan yang mempunyai visi dan tujuan yang jelas. Apabila ada kegiatan yang sekiranya tidak bermanfaat pada dirinya maka sudah otomatis pemuda yang sering mengikuti kegiatan karang taruna akan cenderung tidak mengikutinya dan memilih kegiatan lain yang bermanfaat. Selain itu juga terlihat dari cara dia berkomunikasi. Mereka yang biasa mengikuti musyawarah, seminar, diskusi ataupun perkumpulan lainnya jelas terlihat lebih bisa menghargai dan pola pikirnya sangat berbeda.

Kebiasaan di desa bahwa pemberitahuan yang dilakukan oleh pemimpin itu merupakan suatu perintah yang harus dijalankan. Seperti halnya sambatan, seharusnya tidak ada komando dari atasan maka masyarakat sudah otomatis melakukannya dan apabila ada perintah, maka hal itu menjadi suatu keharusan. Sebenarnya dalam karang taruna adalah pembentukan jati diri bagi adik-adik yang menginjak remaja, SMP-SMA. Seharusnya mereka difokuskan untuk membentuk jiwa sosial yang merupakan keterampilan masa depannya. Dalam kehidupan sosial diperlukan keterampilan juga untuk bagaimana hidup bermasyarakat. Pemuda yang sedang mencari jati diri, seharusnya bisa mengembangkan potensi desa, selain itu juga bisa menggali wawasan dari luar untuk menambah pengetahuannya. Pemuda diharapkan memiliki jiwa sosial yang tinggi supaya bisa memahami arti dari kebersamaan. Beban sendiri yang dipikul menjadi ringan dan lebih efisien. Terlebih ada transfer ilmu proses pendidikan antar sesama.

Kita semua tidak bisa menyalahkan pemuda apabila mereka berbuat kesalahan dalam masyarakat. Karena mungkin dari diri kita sendiri terdapat kesalahan yang tidak sengaja diperhatikan oleh pemuda. Yang pertama kita lakukan adalah dengan memperbaiki perilaku kita dihadapan pemuda. Perilaku baik yang utama kita tunjukkan pada 
mereka, pada akhirnya dapat diikuti dan menjadi cermin pada mereka untuk kedepannya yang lebih baik. Keteladanan dan contoh itulah yang seharusnya menjadi poin penting dalam lingkungan. Kedua, yaitu dengan membangun kesadaran pada diri mereka para pemuda untuk bercermin apakah yang dilakukan benar-benar sudah bermanfaat. Faktor yang mempengaruhi tidak hanya dari luar saja akan tetapi juga dari dalam diri pemuda itu.

Sambatan menjadi suatu sistem norma dan pedoman masyarakat dalam gotong royong dan tolong-menolong. Bukan saja kegiatan dan pelaksanaannya saja akan tetapi juga nilai-nilai yang terkandung dalam sambatan menjadi patokan dan aturan main. Nilai-nilai yang ada dalam tradisi sambatan tidak hanya dipelajari sebagai teori saja, akan tetapi juga harus dilaksanakan dalam kehidupan sehari-hari. Tentunya mulai dari sekarang pemuda harus lebih giat dan sering mengikuti sambatan untuk membentuk karakter yang peduli dengan lingkungannya. Sesuai dengan pernyataan Abdullah (1994, hlm. 1) menyatakan bahwa: Pemuda atau generasi muda adalah konsepkonsep yang sering diberati oleh nilai-nilai. Hal ini terutama disebabkan karena keduanya bukanlah semata-mata istilah ilmiah tetapi sering lebih merupakan pengertian ideologis atau kultural. Pemuda sebagai harapan bangsa, pemuda harus dibina. Semua itu memperlihatkan saratnya nilai-nilai yang melekat pada kata pemuda.

Pelaksanaan tradisi sambatan oleh pemuda pada dasarnya adalah untuk mengimbangi budaya asing yang masuk yang mungkin bertentangan dengan budaya Indonesia. Oleh karena itu, pemuda harus lebih sering lagi diajak dan didampingi untuk mengikuti kegiatan kemasyarakatan. Upaya masyarakat dalam tradisi sambatan untuk meningkatkan apresiasi pemuda mengikuti sambatan adalah dengan membangun rasa kebersamaan melalui kegiatan yang menarik, mengaplikasikannya dalam kegiatan sehari-hari, pengawasan dan pendampingan orang tua kepada pemuda khususnya kepada anaknya, dan yang terakhir adalah jangan menghakimi atau terlalu banyak menyalahkan pemuda sebagai perusak segalanya. Masyarakat yang menjunjung tinggi nilai-nilai dan norma yang berlaku dalam masyarakat adalah masyarakat yang peduli dengan lingkungannya. Sehingga dalam kenyataannya menunjukkan bahwa mereka mampu menjaga dan mempertahankan tradisi yang berlaku dalam masyarakat. Masyarakat yang demikian itu bisa dikatakan masyarakat yang berpranata.

Menciptakan lingkungan yang aman, tenteram dan nyaman adalah tanggung jawab kita semua. Memiliki kebiasaan yang saling tolong menolong, peduli, dan tanggung jawab sosial dalam masyarakat adalah proses yang panjang yang berawal dari tradisi dan kebiasaan suatu masyarakat. Kebiasaan yang dilakukan berulang-ulang akan menjadi kebudayaan yang wajib dan sangat diperlukan oleh masyarakat. seperti yang diungkapkan oleh Coleman (dalam Sumantri, 2005, hlm. 45) bahwa: Budaya dalam arti luas dianggap sebagai pengetahuan dan nilai nilai yang diturunkan dari generasi ke generasi dalam sebuah kelompok sosial. Pemahaman nilai-nilai sebagai unsur dan hakikat kebudayaan sangat penting dalam mempelajari antropologi budaya.

Menciptakan suatu inovasi baru dari tradisi sambatan dengan mengaitkan kebudayaan baru adalah sesuatu yang baik dan bagus untuk dilakukan dengan tidak menghilangkann makna dari tradisi sambatan itu. Pada intinya sambatan adalah pekerjaan yang memerlukan keikhlasan dan mental yang bagus untuk menjalaninya. Dalam kegiatan pawai buah yang diadakan oleh kecamatan, karang taruna mengikutinya dengan lancar. Kegiatan pawai ini dalam pelaksanaan dan persiapannya memerlukan banyak orang dan tidak mungkin diselesaikan oleh satu orang saja. 
Salah satu upaya untuk menarik perhatian pemuda supaya berkumpul dengan karang taruna adalah adanya pelatihan akan memberikan bekal pemuda untuk kedepannya. Menjalankan Peraturan Menteri Sosial Republik Indonesia No. 83/ HUK/ 2005 tentang Kedudukan, Tugas Pokok dan Fungsi dalam pasal 3 Ayat 3, yaitu: Setiap karang taruna melaksanakan fungsi: a) Penyelenggara Usaha Kesejahteraan Sosial, b) Penyelenggara Pendidikan dan Pelatihan bagi masyarakat. Khususnya generasi muda sesuai dengan kebutuhan dan kemampuan yang dimilikinya, c) Penyelenggara pemberdayaan masyarakat terutama generasi muda di lingkungan secara komprehensif, terpadu dan terarah serta berkesinambungan, d) Penyelenggara kegiatan pengembangan jiwa kewirausahaan bagi generasi muda di lingkungannya, e) Penanaman pengertian, memupuk dan meningkatkan kesadaran tanggung jawab sosial generasi muda, f) Penumbuhan dan pengembangan semangat kebersamaan, jiwa kekeluargaan, kesetiakawanan sosial dan memperkuat nilai-nilai kearifan lokal dalam bingkai Negara Kesatuan Republik Indonesia, g) Pemupukan kreativitas generasi muda untuk dapat mengembangkan tanggung jawab sosial yang bersifat rekreatif, kreatif, edukatif, ekonomis produktif dan kegiatan praktis lainnya dengan mendayagunakan segala sumber dan potensi kesejahteraan sosial di lingkungannya secara swadaya, h) Penyelenggaraan rujukan, pendampingan, dan advokasi sosial bagi penyandang masalah kesejahteraan sosial, yang dimaksud adalah fakir miskin, penyandang cacat, anak terlantar/ anak jalanan/ anak nakal, lanjut usia terlantar, tuna sosial, korban napza, korban bencana wanita rawan sosial ekonomi, i) Penguatan sistem jaringan komunikasi, kerjasama, informasi dan kemitraan dengan berbagai sektor lainnya, j) Penyelenggara usaha-usaha pencegahan permasalahan sosial yang aktual. Melatih pemuda supaya mandiri tidak menggantungkan hidupnya pada sesuatu yang tidak pasti. Selain itu juga mengurangi angka pengangguran. Hal itu akan lebih baik apabila dikembangkan lagi sehingga mempunyai prestasi yang bisa dibanggakan. Ketika pemuda kita hargai keberadaannya, insyaallah mereka juga akan mendengarkan ajakan kita. Istilahnya dengan cara pelan-pelan kita mengajak mereka. Pemuda jangan selalu disalahkan, jangan membuat mereka merasa tertekan karena mereka sangat dibutuhkan dalam masyarakat. Mereka juga dalam proses pembentukan karakter, sehingga yang namanya proses perlu diluruskan kembali. Pembentukan karakter dalam masyarakat sangat penting karena itu juga wujud nyata dari pendidikan yang diperoleh dalam sekolah.

Nilai yang selanjutnya adalah dengan adanya kompetisi, diharapkan pemuda mempunyai ide dan kreativitas untuk menciptakan sesuatu untuk ditampilkan. Bentuk kreativitas yang diharapkan adalah sesuai dengan norma-norma yang ada dalam masyarakat. Tidak menyinggung atau menghina pihak lain, menciptakan karya yang bagus, ajang untuk menciptakan tingkat kreativitasnya, dan lain-lain. Sehingga dengan kesibukan dan fokus kegiatan positif akan mengurangi tingkat kenakalan remaja maupun kegiatan yang tidak bermanfaat oleh pemuda.

Proses Pembentukan Karakter Pemuda dalam Masyarakat: 1) Cara pandang pemuda terhadap tradisi sambatan sebagai media pembentukan karakter kepedulian, (mindset), 2) Tindakan Peduli dan gotong royong (action), 3) Kebiasaan (habbit), 4) Karakter Pemuda yang sesuai dengan nilai Pancasila (character), 5) Pemuda berkarakter.

\section{PENUTUP}

Tradisi sambatan adalah kebiasaan warga dalam gotong royong tolong-menolong dalam kehidupan sehari-hari baik itu untuk kepentingan pribadi maupun untuk kepentingan 
umum. Kemauan mengikuti sambatan diperlukan keikhlasan dan kepedulian yang tinggi tanpa mengharapkan imbalan dari siapapun. Oleh karena itu, tradisi sambatan bisa melatih dan membentuk karakter pemuda yang peduli terhadap lingkungannya. Adanya tradisi ini bisa membuktikan bahwa dalam kehidupan modern ini ada kebiasaan warga yang sangat peduli terhadap kepentingan orang lain. Untuk mempertahankan tradisi dan pembentukan karakter yang lebih baik adalah pemuda yang sangat berperan dalam hal ini. Pemuda harus bisa belajar dan mempertahankan tradisi ini supaya kehidupan kedepannya yang lebih baik. Selain mempertahankan tradisi sambatan, kehidupan ekonomi pemuda juga harus dipikirkan. Kesejahteraan mereka menjadi tanggung jawab kita semua untuk tetap menjaga kondisi ekonominya. Ketika pemuda mampu berkarya dan menghasilkan uang untuk memenuhi kebutuhan hidupnya, hal itu tidak menjadi kendala utama dalam mengikuti tradisi sambatan. Karang taruna harus mampu menciptakan kondisi dan situasi yang nyaman bagi pemuda untuk berkumpul dan diskusi tentang kehidupan masyarakat. Karena itu, karang taruna menciptakan kegiatan pelatihan untuk memberikan bekal kepada pemuda untuk mengembangkan bakat sesuai tujuan karang taruna yang telah ditetapkan oleh pemerintah.

Adapun rekomendasinya adalah: 1) Kepada Pemerintah, mengeluarkan beberapa kebijakan yang memihak kepada pemuda. Pemerintah memberikan beberapa fasilitas yang memadai untuk menarik perhatian pemuda supaya beralih kepada kegiatan yang positif. Optimalisasi Undang-Undang Nomor 40 Tahun 2009 tentang Kepemudaan dan Peraturan Menteri Sosial Republik Indonesia No. 83/ HUK/ 2005 tentang pedoman dasar karang taruna sebagai landasan hukum penyelenggaraan karang taruna harus dilaksanakan sebagaimana mestinya; 2) Kepada Karang Taruna, dapat mengkoordinir dan mengayomi seluruh pemuda di desa agar dapat maksimal berperan dalam masyarakat, perlu ditingkatkan kembali kegiatan yang dapat memberikan kontribusi dan pelatihan yang sesuai dengan pemuda setempat, koordinasi dan kerjasama antara karang taruna dengan organisasiorganisasi yang lain agar Pendidikan Karakter di Jogorogo dapat berjalan searah, bisa menjalankan fungsinya sebagai pusat informasi bagi pemuda lainnya. Sehingga banyak yang tertarik untuk berkumpul dengan karang taruna. Menjadikan karang taruna sebagai rumah kedua dalam masyarakat, dan tempat berkomunikasi sesama pemuda lainnya; 3) Kepada Pemuda, harus memiliki berbagai kemampuan dan pengetahuan yang luas, maka harus bergabung dalam karang taruna, peningkatan wawasan dan kecendekiawanan tidak dapat berjalan secara instan, oleh karena itu ketika bergabung dalam karang taruna haruslah dapat memberikan kontribusi atau manfaat dan peningkatan kualitas diri; 4) Kepada Warga Masyarakat, selalu mengajak dan memberikan kesempatan kepada pemuda untuk ikut serta dalam tradisi sambatan. Mengawasi dan memberikan dorongan, motivasi dan saran kepada mereka agar senantiasa terkontrol dan tidak berbuat kesalahan. Pendidikan karakter dalam masyarakat harus dapat berjalan secara kolektif dan meningkatkan perilaku baik pemuda, terbebas dari kepentingan individu dan atau golongan, bertujuan untuk peningkatan wawasan, pengetahuan, bakat dan kemampuan pemuda, setiap masyarakat harus memiliki perilaku baik untuk memberikan keteladanan pada pemuda, yakni memancing tindakan baik, menghargai perbedaan, dan memberikan nasihat kepada mereka serta ketauladanan.

\section{DAFTAR PUSTAKA}

Abdillah, Baiquni. (2011). Gotong Royong Cermin Budaya Bangsa Dalam Arus Globalisasi. Dalam makalah Seminar. Hlm. 8-9. Yogyakarta. Amikom 
Abidinsyah. (2012). Internalisasi Nilai Peduli Lingkungan Melalui Pembelajaran Berbasis Kearifan Lokal. Jurnal Integritas, 10 (1), 118

Abdullah, Taufik. (1994). Pemuda Dan Perubahan Sosial. Jakarta. LP3ES

Azis Wahab, A. dan Sapriya. (2011). Teori dan Landasan Pendidikan Kewarganegaraan. Bandung: Alfabeta

Budimansyah, D dan Suryadi, K.(2008). PKn dan Masyarakat Multikultural. Bandung: Sekolah Pascasarjana Program Pendidikan Kewarganegaraan Universitas Pendidikan Indonesia.

Kaelan. (2013). Negara Kebangsaan Pancasila. Yogyakarta: Paradigma

Kementerian Pendidikan Nasional. 2010. Panduan Pelaksanaan Pendidikan Karakter. Jakarta

Koentjaraningrat. (1990). Pengantar Ilmu Antropologi. Jakarta. Rineka Cipta (1985). Kebudayaan Mentalitas dan Pembangunan. Jakarta. Gramedia

Lickona, Thomas. (2012). Educating For Character. Jakarta: Bumi Aksara

Mangunhardjana, A. M. (1989). Pendampingan Kaum Muda. Yogyakarta. Kanisius

Maryani, Sri. (2012). BUDAYA "SAMBATAN" DI ERA MODERNISASI(Study Kasus Di Desa Gumukrejo, Kecamatan Teras, Kabupaten Boyolali). Dalam Makalah
Seminar. Hlm. 7. Surakarta. Universitas Sebelas Maret.

Quthb, Muhammad Ali. (2007). 50 Nasihat Rasulullah Untuk Kaum Muda. Bandung: Mizania

Soekanto, Soerjono. (2002). Sosiologi Suatu Pengantar. Jakarta: Raja Grafindo Sugiyono. (2009). Memahami Penelitian Kualitatif. Bandung: Alfabeta.

Saebani, A. B. (2012). Pengantar antropologi. Bandung. Pustaka Setia

Soekanto, Soerjono. (1990). Sosiologi Suatu Pengantar. Jakarta: Raja Grafindo Persada.

Suryadi, K. dkk. (2014). Idrus Affandi Pendidik Pemimpin Mendidik Pemimpin Memimpin Pendidik. Bandung. Universitas Pendidikan Indonesia

Undang-Undang Negara Republik Indonesia Nomor 40 tahun 2009 tentang Kepemudaan pasal 16

Winarno. (2013). Pembelajaran Pendidikan Kewarganegaraan. Jakarta: Bumi Aksara.

Winarno. 2013. Pembelajaran Pendidikan Kewarganegaraan. Isi, Strategi, dan Penilaian. Jakarta. Bumi Aksara

Sapriya. (2008). "Perspektif Pemikiran Pakar tentang Pendidikan Kewarganegaraan dalam Pembangunan Karakter Bangsa (Sebuah Kajian Konseptual-Filosofis dalam Pendidikan Kewarganegaraan dalam Konteks Pendidikan IPS". Jurnal Acta Civicus. 1, (2), 